\title{
María y El Alférez Real: de Jorge Isaacs a Eustaquio Palacios. Tras la huella de una narrativa patriarcal y burguesa en el Valle del Cauca*
}

DOI: https://doi.org/10.18046/recs.i26.2526

María and El Alférez Real:from Jorge Isaacs to Eustaquio Palacios. Following in the Footsteps of a Patriarchal and Bourgeois Narrative in Valle del Cauca

María e El Alférez Real: de Jorge Isaacs a Eustáquio Palacios. Depois da pegada de uma narrativa patriarcal e burguesa no Valle del Cauca

\author{
GUSTAVO ALEJANDRO ALZATE MÉNDEZ ${ }^{* *}$
}

Universidad Católica (Cali, Colombia)

\footnotetext{
* Proyecto de investigación: «Entre la secularización y el catolicismo: una aproximación histórico-literaria a las novelas María, de Jorge Isaacs, y Cumandá, de Juan León Mera. Un estudio de caso: 1810-1880». Fecha de inicio: 2013, fecha de culminación: 2017.Artículo recibido el 13-10-2017 y aceptado el 16-07-2018.

** Doctor en Literatura por la Universidad de Navarra y docente de las universidades San Buenaventura y Católica de Cali. Su línea de investigación principal es novela hispanoamericana e historia del siglo XIX. Entre sus distinciones se destacan el premio de periodismo Alfonso Bonilla Aragón (2006), y el reconocimiento como mejor docente de la Facultad de Humanidades y Ciencias Sociales de la Pontificia Universidad Javeriana Cali (2012). ORCID: http://orcid. org/oooo-0oo2-0832-0223
} 


\section{Cómo citar}

AlZATE MÉNDEZ, G. (2018). María y El Alférez Real: de Jorge Isaacs a Eustaquio Palacios. Tras la huella de una narrativa patriarcal y burguesa en el Valle del Cauca. Revista CS, 26, 145-17o. https://doi.org/10.18046/recs.i26.2526 
Resumen

Abstract

Resumo

El presente artículo tiene por objetivo analizar y describir tanto la presencia y significado de la burguesía agraria en el Valle del Cauca, como los valores morales y económicos inherentes a esta. María y El Alférez Real, las dos novelas regionales más representativas del siglo XIX, constituyen el escenario de indagación ideal; no solo por su carácter fundacional de la literatura del suroccidente colombiano, sino por sintetizar en sí las tensiones y ambigüedades propias del período posindependentista; el mismo que se debatía entre la pretensión de libertad y el continuismo de la mentalidad colonial.

PALABRAS CLAVE:

María, Alférez Real, siglo XIX, literatura vallecaucana y colombiana

This article aims to analyze and describe both the presence and meaning of the agrarian bourgeoisie in Cauca Valley and the moral and economic values inherent to it. María and El Alférez Real, the two most representative regional novels of the nineteenth century, are the ideal inquiry scenario; not only because they are foundational of the literature of the south-west of Colombia, but also because they reflect the tensions and ambiguities typical of the post-independence period, which was torn between pretension to freedom and an ongoing colonial mentality.

\section{KEYWORDS:}

María, Alférez Real, 19th Century, Valle del Cauca and Colombian Literature

O objetivo deste artigo é analisar e descrever a presença e a significância da burguesia agraria no Valle del Cauca, bem como os valores morais e econômicos inerentes a ela. María e El Alferez Real, os dois romances regionais mais representativos do século XIX, constituem o cenário ideal de investigação. Não apenas por causa de sua natureza fun- 
dacional da literatura do sudoeste colombiano, mas também por sintetizar as tensões e ambiguidades do período pós-independência; o mesmo que foi debatido entre a pretensão de liberdade e a continuidade da mentalidade colonial.

\section{PALAVRAS CHAVE:}

María, Alférez Real, século XIX, literatura vallecaucana e colombiana 


\section{Contextualización}

El estudio de la novelística vallecaucana del siglo XIX convoca hasta hoy diversos intereses. Unos crítico-formales que evalúan originalidades estilísticas en el marco de las tensiones entre los romanticismos europeo e hispanoamericano; y otros más interpretativos, cuyo objetivo es sumarse a la indagación que existe en torno a los procesos de construcción cultural, patriarcal, moral y económica de la región. Dentro de esta segunda categoría se inscribe el presente artículo. En virtud de ello, son varios los puntos de encuentro o diálogo entre estas dos obras fundacionales de la narrativa del Valle del Cauca. Antes de explicar el porqué de esta afirmación, es pertinente sintetizar cuál es el argumento de «El Alférez Real» dada la inferioridad de estudios críticos en comparación con «María».

$\mathrm{Al}$ igual que en la novela de Isaacs, dos jóvenes, Daniel y doña Inés de Lara y Portocarrero, se enamoran. No obstante, su relación es inviable en principio porque el joven, hasta que todo se esclarece, carece de la categoría social y la prestancia económica que se requiere para acceder a una beldad de tal riqueza y clase. Mientras esta aparente realidad domina casi la totalidad de la narración, Daniel se granjea fácilmente los afectos del alférez don Manuel tras servirle como amanuense. Debido a esto, se le trata con notable deferencia hasta el final de la historia. El único revés de don Manuel hacia Daniel acontece cuando se entera por su compadre, el padre Escobar, que el joven pretende a Inés para que sea su esposa.

La molestia del patriarca es enardecida, pues no concibe que su servidor, blanco de tez pero escaso de fondos, ose pretender a tan refinada belleza. «Imposible es que se casen. Desde todo punto, compadre. Ha hecho muy mal ese mozo en levantar sus pensamientos a tanta altura. ¿Casarse él con ella? No toleraría yo jamás semejante escándalo» (Palacios, 1960: 261). A pesar de la desaprobación -tardía, por cierto-, el enamoramiento tímido de los jóvenes tiene ya sólidas raíces. Entre el afecto y la sanción, se genera y alimenta el sentimiento que al final será felizmente recompensado, cosa que no sucede en «María».

El amor entre Daniel e Inés lo supera todo, incluida la estratagema con la cual don Fernando de Arévalo, acaudalado pretendiente de esta última, intenta derrotar al héroe; es decir, a Daniel. Un año desaparece este de la hacienda del alférez, a causa de un irregular alistamiento en las tropas del ejército que se aprestaban para servir en la ciudad de Cartagena. Pasado este tiempo, el muchacho regresa al Valle del Cauca y logra su cometido con la generosa ayuda del padre Escobar: casarse con doña Inés, quien resulta no ser más rica que él pues al revelarse la verdadera identidad de Daniel se descubre que es hijo del ya fallecido primo del alférez don Manuel, con lo cual se garantiza su sangre noble y también su riqueza. «¿Tu apellido? ¿Deseas 
saber tu apellido? Pues bien, tu apellido es Cayzedo. ¡Cayzedo! exclamaron a una Inés y Daniel. Sí, Cayzedo: eres mi primo» (Palacios, 1960: 278).

A diferencia de «María», en «El Alférez Real» la tragedia es pasajera y no determina la infelicidad de los personajes. Al imponerse el final feliz se rompe la fatalidad imperante en la novela de Isaacs. Hecha esta breve síntesis, se vuelve sobre lo dicho al comienzo de este apartado en torno a las similitudes entre ambas obras. A pesar de haber sido escritas con una diferencia de tan solo diecinueve años-«María» en 1867 y «El Alférez Real» en 1886-, la correspondencia de temas, dramas, tramas, representación de los modos de producción económica, romances, disposiciones familiares, sanciones de clase y percepciones de la sociedad de la época acontecen de modo similar. Para dar cuenta de esto, se propone profundizar en las siguientes categorías de análisis: a) predominancia del patriarcado y b) legitimación de la sociedad burguesa.

\section{El Valle del Cauca: región de patriarcas}

Tal como ha referido un amplio sector de la crítica literaria colombiana e hispanoamericana (Florián-Buitrago, 2008) ambas novelas reafirman el patriarcado. No es impedimento para esto el hecho de que las acciones transcurran en épocas diferentes. Como acertadamente señalan los estudiosos (Álvarez Gardeazábal, 200o) la trama de «María» puede ubicarse antes de 1850, mientras que la de «El Alférez Real», como queda dicho desde el capítulo I, «De Cali a Cañasgordas», acontece en 1789. «A principios del mes de marzo de 1789, un sábado, como a las cinco y media de la tarde, tres jinetes bien montados salían de Cali, por el lado del sur, en dirección a la hacienda de Cañasgordas» (Palacios, 1960: 9).

No obstante las diferencias de tiempo, ambos autores -Isaacs y Palacios- dieron cuenta del conjunto de tradiciones de su época. Dentro de estas, las domésticas ocuparon un destacado lugar puesto que el núcleo familiar constituía la metáfora por excelencia del proceso de conformación estatal en Colombia. En consecuencia, el padre se entronizaba como director supremo de la vida, destino y bienestar de los a él subordinados. He ahí como surge la correspondencia entre la figura del paterfamilias y la del jefe de Estado; situación que le confiere al primero una autoridad no solo indiscutible, sino amparada por formas de institucionalidad como la eclesial y la jurídica de arraigo español. A continuación, se propone analizar cómo es y qué significa y determina la presencia del alférez don Manuel de Cayzedo y Tenorio en el espacio tiempo de la narración de Eustaquio Palacios. 
Para empezar, es preciso decir que era él un rico hacendado, al igual que el padre de Efraín. Entre sus posesiones se destacaba la hacienda Cañasgordas, poderoso epicentro económico del suroccidente colombiano. De acuerdo con el historiador Edgar Vásquez Benítez (2001), «esta burguesía agrario-exportadora articuló la gran propiedad territorial, la actividad agrícola, el comercio y la exportación» (27). Lo anterior implica la revisión de la figura patriarcal desde la perspectiva del hombre de negocios, de títulos de nobleza y éxito económico. En lo que concierne al espíritu de comerciante y a la caracterización de potentado del alférez la novela ofrece tempranas pistas. Ya en el capítulo II, «La hacienda de Cañasgordas», se describe lo siguiente:

La riqueza de la hacienda consistía en vacadas tan numerosas, que el dueño mismo no sabía fijamente el número de reses que pacían en sus dehesas, aunque no ignoraba que pasaban de diez mil: era casi tan opulento como Job, quien por su riqueza «era varón grande entre todos los orientales», antes de ser herido por la mano de Satanás. Allí había partidas de ganado bravío, que nunca entraban en los corrales de la hacienda, ni toleraban que se les acercara criatura humana. Además de las vacadas, había hatos de yeguas de famosa raza (Palacios, 1960: 22).

Cabe advertir que más allá del asunto ganadero, el poder económico del alférez descansa también en otras formas de explotación comercial. Una de ellas, con honda significación, tiene que ver con la plantación agrícola y esclavista. De la primera puede sintetizarse lo siguiente: «había además extensas plantaciones de caña dulce con su respectivo ingenio para fabricar el azúcar, grandes cacaotales y platanares en un sitio del terreno bajo llamado Morga»(Palacios, 1960: 22). De la plantación esclavista, a su vez, se precisa que «esclavos había más de doscientos, todos negros, del uno y del otro sexo y de toda edad; estaban divididos por familias, y cada familia tenía su casa por separado» (Palacios, 1960: 23).

La conjunción de los elementos observados (ganado, esclavos y cultivos) permite establecer la pervivencia de ecos coloniales que fueron captados, bien por sensibilidad, herencia o continuismo, por la literatura decimonónica colombiana. ¿A qué se alude con esto? Tan solo diecinueve años después de que Isaacs escribiera «María», Palacios reactualizó toda la esencia del pasado colonial o por lo menos gran parte de esta. Esto, hay que decirlo, es verosímil, puesto que el tiempo en el que transcurren los hechos va mucho más atrás que el de «María».Lo contado en «El Alférez Real» se articula en lo cronológico, lo político y lo moral con el momento histórico en que la nación aún se hallaba bajo dominio español.

Es precisamente este juego temporal lo que permite a Eustaquio Palacios realizar una cuidada elaboración de la historia del Valle del Cauca de su tiempo, de su gente y tradiciones. Nada en la obra violenta el conjunto de costumbres católicas, domés- 
ticas y de clase propias de la jerarquización social colonial. Con esto, el Valle esboza incipientemente el nacimiento de una burguesía terrateniente no solo portadora de singulares conceptos morales, sino excluyente, dogmática y pro española. Ahora bien, esto no impide que como parte del proceso de construcción del proyecto regional católico, que se articula con la creación de la nación, las élites sean revestidas de cierta conciencia social que romantiza, por ejemplo, el drama a todas luces inhumano de la esclavitud. Para dar cuenta de estas articulaciones y diálogos entre lo económico, lo moral, lo regional y lo social, Eustaquio Palacios elaboró lo que hasta ahora constituye uno de los más cuidados procesos de indagación documental. No en vano, diversos estudios han enfatizado que el principal acierto de la novela es el excelente trabajo de archivo y documentación histórica.

Las virtudes de la novela se deben al rigor documental que la sustenta, a la precisión del detalle y a la visión de conjunto que logra recrear. Se refiere a hechos ocurridos en la ciudad de Cali y en sus inmediaciones durante los últimos años del siglo XVIII, en especial los comprendidos entre 1789 y 1792, siendo virrey de la Nueva Granada José de Ezpeleta y gobernador de Popayán don Pedro de Beccada y Espinosa, a quienes se menciona en la narración. Las fuentes más importantes utilizadas por Palacios son las actas del Ayuntamiento, algunas de las cuales transcribe en su totalidad. Incluye, por ejemplo, la lista de los funcionarios públicos, sus títulos o cargos, y la forma como votaban. La extensión y el detalle de estas transcripciones contribuyen al realismo, pero no se justifican desde el punto de vista de la trama. Cumplen, según creo, con la finalidad secundaria de exaltar la prosapia de ciertas familias cuyos descendientes, cien años después, eran figuras prestantes de la sociedad en que vivía Palacios. La novela evidencia, además, el trabajo de archivo desarrollado por el autor en notarías y registros parroquiales (Pineda Botero; 1999: 72). En torno al copioso y evidente proceso de recopilación de datos de época, es preciso destacar que es diferente al de «María»; razón por la cual no podría asumirse como superior o mejor logrado. Las indagaciones y observaciones hechas por Isaacs a la sociedad de su tiempo fueron resultado directo de su conocimiento experiencial del país. En su condición de poeta, político, militar, etnógrafo y expedicionario, no solo entendió y dimensionó el contexto geográfico sino que entendió la idiosincrasia de la gente en Colombia. Desde esa perspectiva, estudió con ahínco la diversidad racial así como los diferentes capitales culturales, rituales, lingüísticos y ancestrales que estructuraron desde temprano el carácter pluriétnico y multicultural de la nación. De no ser así, los extensos capítulos de la africanía que protagonizan «Nay y Sinar» no tendrían la fuerza para, como precisa el investigador Darío Henao (2005), «proveer el sustrato histórico de la novela» (51). 
Con lo dicho hasta aquí podría surgir el siguiente interrogante: ¿qué metodología de investigación articula el cuidado proceso de observación social realizado por ambos autores, con el análisis textual de las formas, ritmos y tensiones de la sociedad patriarcal que ahora se propone? Responder esta pregunta implica señalar que, dada la articulación entre texto y contexto social, la sociocrítica se erige como el camino más expedito para explicar tanto las articulaciones entre literatura e historia como para analizar los códigos de época en relación con la formación del incipiente concepto de región. De acuerdo con Eva Kushner (2009), «el texto literario crea un espacio dialógico que permite al lector insertarse en la historia a través de aquél. Esto quiere decir a la vez que el texto literario no es aislable del discurso social en ningún caso, y que tiene, o por lo menos puede tener, una función propia en el seno de aquél» (141).

En ese sentido, las observaciones a los entornos sociales, políticos, económicos y espirituales presentes en las novelas han ayudado a definir y caracterizar a patriarcas como el alférez don Manuel y al padre de Efraín, quienes definen no solo las jerarquías intratextuales, sino que toman para sí-o son dotados de-algunas de las marcas, costumbres y creencias de los propios autores. Con esto último no se pretende caer en lo que Noé Jitrik (2005) ha denominado la «tentación prologuista o enciclopédica, típica de las historias de la literatura que no se proponen ir más lejos que los prólogos» (13); por el contrario, se busca poner en evidencia la correspondencia entre autor y obra con el fin de lograr una mejor interpretación, tanto de la época, como de las configuraciones de mundo que se representan de acuerdo con la procedencia de cada escritor.

Esto se puede ver de la siguiente forma: si bien la procedencia de Jorge Isaacs y Eustaquio Palacios es distinta en cuanto a los lazos de sangre con el extranjero, por ejemplo, cabe advertir que ambos tuvieron destacados cargos en la política local, lo cual les granjeó un vasto conocimiento económico, jurídico y cultural de su región, el Valle del Cauca. Mientras Isaacs ocupó diversos cargos diplomáticos y administrativos, como cónsul en Chile durante 1871 y 1872, superintendente general de Instrucción Pública Primaria en el Estado del Cauca en 1875 y, posteriormente, en el de Tolima entre 1883 y 1884; Eustaquio Palacios, por su parte, fue secretario, miembro y presidente del Cabildo. Durante diez años, de 1866 a 1876, ejerció el rectorado del Colegio de Santa Librada, presidió la primera municipalidad de la provincia en el año de 1864 y en los de 1873 y 1879, fue además Administrador Provincial de Hacienda Nacional, inspector de instrucción pública y magistrado del tribunal de occidente (Palacios, 1960: 1).

Al traer a colación estos datos se intenta explicar, mediante una suerte de intercalación, el carácter hegemónico de los patriarcas en ambas novelas. En tanto hombres 
de poder y acción política, Isaacs y Palacios elaboraron un arquetipo patriarcal que sintetizaba el conjunto de creencias, valores y maneras que a ellos mismos los definía como sujetos sociales, pero sobre todo políticos. La hipótesis, por lo tanto, es que el patriarcado se construye desde el lugar hegemónico que tuvieron tanto Isaacs como Palacios. De ahí la sólida elaboración de la conciencia moral, económica y civil de los personajes, pues resulta fácil contrastar cómo la personalidad de cada patriarca no falsea, en lo ficcional, la esencia extraliteraria de los autores. He ahí una de las posibilidades de diálogo y cotejo que permite la sociocrítica. Además de esto, y siguiendo a Umberto Eco (1992) en «Los límites de la interpretación», la correlación entre las intentio auctoris (intención del autor) y operis (intención de la obra), permite develar significados del texto que no se explican, muchas veces, mediante los simples sucesos de la ficción. En consecuencia, al conocimiento de ciertos datos «encubiertos» solo se llega a través de la lectura relacional que se vale del conocimiento biográfico de quien escribe. De acuerdo con Martín Jiménez (2014), «la teoría literaria actual debe prestar atención a todos y cada uno de los elementos implicados en el hecho literario y en la comunicación literaria (autor, texto, receptor, código, contexto, canal, referente y tradición literaria), sin prescindir de ninguno de ellos» (165).

En virtud de lo explicado, y como resultante del conocimiento que Isaacs y $\mathrm{Pa}$ lacios tuvieron de la economía del Valle del Cauca, por ejemplo, es que a cada jefe de familia se le confiere un sólido conocimiento de las distintas rentas regionales; lo cual constituye un factor decisivo si se tiene en cuenta que en tanto líderes y referentes de la burguesía, portaban la responsabilidad de dinamizar el incremento del capital financiero de la región. La sumatoria de las vocaciones empresariales de estos y demás patriarcas, adscritos a distintas filiaciones políticas, es lo que en definitiva permitió poner en marcha la economía agrícola local que gradualmente fue incorporándose al proyecto industrial nacional.

Ahora bien, en «El Alférez Real», tal como sucede en «María», el patriarca no es solo capitalista confeso, sino que, adicionalmente, detenta todas las virtudes del hombre de élite decimonónico: es piadoso, altruista, buen amigo, celoso guardián de las tradiciones y devoto ferviente, además de orgulloso. Todas estas características le confieren los atributos suficientes para ser tanto el centro de la vida social de la comarca como el centro de la vida doméstica de la hacienda, como queda demostrado a continuación.

Al entrar don Juan saludó al padre con cariño y respeto; en seguida don Manuel y el Padre ocuparon las cabeceras de la mesa, doña Francisca se colocó a la derecha de su marido y doña Inés a la izquierda de éste. El padre tenía a don Juan a su derecha y a Daniel a su izquierda; las demás señoritas se sentaron a los lados de la mesa (Palacios, 1960: 17-18). 
La dinámica familiar, que entroniza la figura del padre, no varía mucho si se vuelve la mirada hacia el padre de Efraín.

Carlos y yo nos presentábamos en el comedor. Los asientos estaban distribuidos así: presidía mi padre la mesa; a su izquierda acababa de sentarse mi madre; a su derecha don Jerónimo, que desdoblaba la servilleta sin interrumpir la pesada historia de aquel pleito que por linderos sostenía con don Ignacio; a continuación del de mi madre había un asiento vacío y otro al lado del señor M...; enseguida de éstos, dándose frente, se hallaban María y Emma, y después los niños (Isaacs, 1967: 127).

Esta notoria jerarquización de la vida familiar evidencia cómo la literatura del siglo XIX en Colombia fue proclive a la preservación de tradiciones sociales de vieja data. No obstante, y desde las antípodas, Alfonso López Michelsen sostiene que «después de las guerras de Independencia, se dio un relajamiento de las costumbres existentes hasta fines del periodo colonial, esto en razón de los grandes cambios políticos, económicos, sociales y culturales vividos en la joven República»(Bermúdez, 2008:36). Desde la presente óptica, el diálogo intertextual entre «María» $\mathrm{y}$ «El Alférez Real» no da cuenta de esto.

De existir tal relajamiento, Efraín hubiera sido feliz con María y Daniel se hubiera casado con Inés sin padecer el sufrimiento de saberse inferior y sancionado por su supuesto origen plebeyo. Ambos jóvenes hubieran desatendido los mandatos patriarcales y así cumplido sus voluntades individuales. Ahora bien, López Michelsen instala su crítica en un contexto posterior a las guerras de independencia en Colombia, es decir, después de 1820, tiempo que desde la presente interpretación no es significativo para producir importantes variaciones sociales y menos familiares. Si se parte del hecho de que la influencia de la Iglesia se mantuvo entonces como se mantiene hasta hoy, a pesar de la ingente secularización del Estado, es poco creíble que la familia haya sintetizado en sus dinámicas internas tanto la convulsión como la rebeldía que existía en lo político. Por el contrario, se entiende que la familia decimonónica se erige como el último bastión que preserva los valores católicos y demás propios de la Colonia.

Si bien con las descripciones domésticas expuestas se enmarca la jerarquización de la mesa, escenario por excelencia de las interacciones de la vida familiar, hay otras que se extienden al resto de habitantes de la hacienda, cuya condición es de absoluta subalternidad o subalternidad moderada, como en el caso de Daniel. El alférez don Manuel tiene actitudes, como la que se muestra a continuación, con las cuales se refuerza el estereotipo de patriarca generoso, casi bíblico o mesiánico. 
¿Y qué piensas llevarles para la boda? porque supongo que les llevarás algo. Nada, señor. Eso no puede ser. Dile a Zamora que mande mañana una novilla gorda a Catayá en tu nombre. Yo daré orden a María Francisca para que te dé una botijuela de vino (Palacios, 1960: 130).

En ese mismo contexto de generosidad con el otro, el padre de Efraín, como se aprecia en el capítulo XLV, hace saber a Juan Ángel, hijo de Nay, que es absolutamente libre tras la muerte de esta. Si se indaga desde adentro hacia afuera, es decir, desde el núcleo familiar donde media el afecto hasta el exterior del hogar donde median las relaciones de poder, conveniencia y rentabilidad, es constatable cómo se sostiene la caracterización de ambos patriarcas.

Ni Isaacs ni Palacios modifican el carácter y las maneras distinguidas de los hombres de clase, independientemente de a quién traten y en qué contexto o condición. Esto, dicho sea de paso, reafirma la negativa a la tesis del relajamiento de costumbres que refiere López Michelsen. La coherencia en el establecimiento del mundo patriarcal pasa por la no fractura de las virtudes que posicionan a los padres como líderes del espacio doméstico, económico y espiritual del Valle del Cauca.

En el momento en que los señores de la principalía se consagran como guías y faros de la vida comunitaria, se reafirman las características que los hacen respetables, decorosos y ecuánimes ante cualquier ciudadano o circunstancia. Es por esto que, desde el inicio hasta el final, cada novela mantiene intactos los rasgos morales, éticos y comportamentales de los personajes que detentan el poder. De tal suerte que, en el principio y final de «El Alférez Real», se establece el siguiente estereotipo de don Manuel. Temprano, en el capítulo II, «Doña Inés de Lara», se dice de él:

Su carácter, de verdadero hidalgo castellano, se prestaba a las acciones más generosas, aunque un tanto desigual, pues tan pronto se manifestaba amable como iracundo. Su honradez proverbial y el interés con que propendía siempre a toda mejora de utilidad común, le granjeaban gran prestigio entre sus compatriotas y la general estimación. Era de hecho y de derecho el personaje más importante de la ciudad (Palacios, 1960: 28).

Hacia la parte final de la novela se constata el refuerzo de la imagen idealizada del alférez.

Don Manuel alcanzó una venerable vejez; ya al fin de su vida recibió del rey Carlos IV la señalada distinción de ser nombrado Caballero de la Real y distinguida Orden de Carlos III, que se concedía únicamente a la virtud y al mérito, como lo decía su divisa: Virtuti et merito (Palacios, 1960: 282). 
Por su parte, del padre de Efraín se enfatiza, en el capítulo V, el siguiente rasgo que, a veces de manera poco oportuna, ha romantizado su presencia en el contexto de la esclavitud que aún pervivía en Colombia: «Pude notar que mi padre, sin dejar de ser amo, daba un trato cariñoso a los esclavos, se mostraba celoso por la buena conducta de sus esposas y acariciaba a los niños» (Isaacs, 1967: 21). Hacia el final de la narración se mantiene intacta su probidad, mas se abre una pequeña fisura a través de la cual él se siente apenado por sus inflexibles determinaciones en relación con el viaje de Efraín a Londres. «Yo, decía él, yo, autor de ese viaje maldecido, ila he muerto! Si Salomón pudiera venir a pedirme su hija, ¿qué habría yo de decirle?... y Efraín... y Efraín... ¡Ah! ¿Para qué lo he llamado? ¡Así le cumpliré mis promesas!» (Isaacs, 1967: 404).

Otro rasgo significativo que permite establecer diálogo entre ambas novelas tiene que ver con la participación de ambos patriarcas-padrastros-en el proceso de matrimonio de sus hijastras. Ni Inés es hija del alférez real ni María lo es del padre de Efraín. Sin embargo, en tanto responsables de ellas tras la muerte de sus progenitores biológicos, participan discrecional y convenientemente en sus procesos vitales. En el caso de María, Efraín es hecho a un lado por instrucción de su padre para que Carlos la corteje. «Voy a hablarte de la manera misma que hablaría a Emma en Igual circunstancia. Sí, señora: ya oigo. Tu papá me ha encargado te diga... que el señor de M... ha pedido tu mano para su hijo Carlos» (Isaacs, 1967: 142).

No muy diferente es la situación en «El Alférez Real». Cuando Inés alcanzó la adolescencia, don Manuel se encargó de atender personalmente a los no pocos pretendientes que se acercaron ilusionados. Dentro de estos se destacó don Fernando de Arévalo, quien, en el capítulo X, «La propuesta de don Fernando de Arévalo», manifestó ardoroso interés por contraer nupcias con ella. En pro de ese objetivo se dispuso a seguir todos los protocolos de rigor. Por su parte, don Manuel, convencido de la prestancia y la clase del pretendiente, procedió ante su entenada:

Siéntate, hija, que tenemos que hablar de un asunto muy grave. Inés se sentó en una poltrona de vaqueta que le ofreció don Manuel, y luego, sin poder ocultar su curiosidad, le dijo: veamos, padrino, qué asunto es ese tan grave que me anuncia y que confieso que me causa miedo. Es muy sencillo, ahijada, y en pocas palabras te lo propondré: don Fernando de Arévalo me ha pedido tu mano (Palacios, 1960: 101).

Acontecimientos como estos signan una constante en la novelística decimonónica en Colombia: los matrimonios se convenían entre el jefe del hogar y el pretendiente. Por su parte, las hijas/hijastras accedían a cumplir lo pactado aunque no fuera de su agrado. Las conveniencias económicas y la preservación de la burguesía como clase 
hegemónica constituían lo determinante. «Esta costumbre era general en casi todas las casas principales, así es que los matrimonios se contrataban entre el pretendiente y el padre de la pretendida» (Palacios, 1960: 98).

Así las cosas, y para concluir este primer apartado, solo resta decir que la novelística del siglo XIX en Colombia legitima la autoridad patriarcal como extensión vívida de la autoridad colonial. El sostenimiento de la tradición, cabe precisar, tiene una intención mucho mayor que la idealizada preservación del orden, la moral, la religión y las buenas costumbres. En tanto hecho estético, la literatura textualizó la conformación de poderosos clanes económicos familiares, cuya función consistía en dinamizar el progreso comercial y el asentamiento de la burguesía como clase dominante en el suroccidente del país. La entronización de la figura del padre es, en síntesis, un proceso casi típico si se tiene en cuenta la agitación sociopolítica del siglo XIX. En este período, líderes y caudillos fungieron como patriarcas de las naciones en ciernes. Al tiempo que surgía en la conciencia nacional el concepto de héroe de la patria, se hacía más sólida y venerable la figura del padre de familia en tanto poseedor del poder en el hogar.

\section{Legitimación de la sociedad burguesa}

En lo concerniente a este punto, es importante advertir que el énfasis en los asuntos de clase (tenencia y disputa del poder, posicionamiento social en virtud del reconocimiento de títulos nobiliarios, reconocimiento público, etc.) está más matizado en «El Alférez Real». Con esto no se pretende negar, desde luego, que «María»es también una novela clasista que promueve los valores de la élite regional, al tiempo que plantea una relectura del subalterno y su ubicación en el espacio social y doméstico. Esto último acontece sin dejar de lado el proyecto de consolidación de la sociedad burguesa en el Valle del Cauca, territorio que rápidamente se ubicó como uno de los principales focos de desarrollo del país, dada su variedad agrícola y la ubicación estratégica del puerto de Buenaventura.

Para profundizar más en torno a los mencionados asuntos de clase y la consolidación de la burguesía, se establecerá un diálogo entre ambas novelas a partir de dos ejes temáticos puntuales: a) don Manuel de Cayzedo y Tenorio, alférez real, férreo defensor de la tradición religiosa, la diferenciación de clases sociales y la burguesía emergente, y b) la moral como elemento diferenciador entre las novelas, como condición de superioridad ante los otros. 


\section{Don Manuel de Cayzedo y Tenorio, alférez real, férreo defensor de la tradición religiosa, la diferenciación de clases sociales y la burguesía emergente.}

A lo largo de la narración de Eustaquio Palacios, el alférez don Manuel se erige como el personaje que con mayor empeño defiende la consolidación y asentamiento de la burguesía en el Valle del Cauca. Visto en detalle, es él quien encabeza el conjunto de simpatías que sostienen la jerarquía social de arraigo español. Su presencia en el espacio ficcional no solo genera interpretaciones particulares del contexto geográfico y cultural, sino que sintetiza todo el rechazo hacia las acciones que pudieran llegar a vulnerar el orden social de molde ibérico. Se insiste en esto puesto que la novela es explícita en cuanto a la legitimación del poder católico y monacal proveniente de Europa. Para dar cuenta de ello, véanse a continuación dos situaciones puntuales, la primera sucede en el capítulo $\mathrm{X}$ y se describe de la siguiente manera:

Una de esas orgullosas y nobles señoras -caleñas- podía ver con desdén a un plebeyo; pero si éste llegaba a enfermar de gravedad, deponía al instante su orgullo y se constituía enfermera al borde de la cama del paciente, con tanto mayor esmero cuanto más desvalido fuera. Creemos que de todas las noblezas del mundo la española es la más a propósito para producir hermanas de la caridad (Palacios, 1960: 113).

A partir de esto, pueden inferirse dos intenciones: reforzar la presencia idealizada de la mujer virtuosa en América y-esto es lo más significativo- reivindicar las virtudes morales y espirituales de España. Para Palacios, este país constituyó el modelo de sociedad ideal, sobre todo altruista y caritativa. La segunda situación acontece en el capítulo XII, «La jura de Carlos IV», así: «el buen pueblo caleño manifestaba querer probar su lealtad y amor a su soberano» (Palacios, 1960: 219).

Estos dos ejemplos, entre otros, estructuran tanto el carácter clasista de la novela de Palacios como las simpatías generales hacia la figura del rey, signo supremo del poder colonial. Las interacciones que propone la obra a partir de la relación pueblo-poder son armónicas y exentas de cualquier tensión capaz de fracturar la simpatía comunitaria por las formas de gobierno español. Desde la presente lectura, Eustaquio Palacios no funda, sino que reacomoda el territorio geográfico, económico y espiritual ya advertido por Isaacs en «María». Lo novedoso de su novela, dada la estructuración de la trama, radica en el gozoso saldo de las deudas históricas entre dominados criollos y dominadores españoles. Es decir, en «El Alférez Real»se textualizan interacciones en las cuales no hay malestar con respecto a Europa por la dominación colonial. La novela se exime de la crítica histórica y la observación 
objetiva de los hechos que en América significaron el violentamiento de un pasado sociocultural rico y autónomo.

Al evadir la indagación crítica, lo que resulta en la trama es la legitimación del modelo político, social y cultural europeo. Más allá de la personalidad del alférez, de la presencia del padre Escobar y de toda la réplica de las formas de vida española, hay un hecho clave en la novela que soporta el carácter pro hispánico que se pretende evidenciar: la presencia de Juan Zamora dentro del séquito de servidores de don Manuel. En el capítulo IV, «Daniel», se le describe de la siguiente forma:

Don Juan Zamora era un español de gran talla, muy esforzado y de buen carácter. Era andaluz, y a pesar de eso, en su lenguaje se percibían la c y la z bien pronunciadas con sus sonidos dentales. Los amos lo trataban con mucha familiaridad y lo admitían por la noche en sus conversaciones en la sala; las señoras gustaban de jugar con él a los naipes, juego en el cual siempre perdía porque los muchachos le hacían trampa, mientras que él era incapaz de hacerla. Rígido en el cumplimiento de su deber, era, sin embargo, afable con los esclavos. Así eran los demás españoles que había entonces en Cali, que no eran pocos: hombres formales, esclavos de su palabra, celosos de su dignidad. Difícil habría sido ver a unos de estos tocando el organillo en una esquina para ganar la subsistencia. El hidalgo castellano en América, cuando era pobre, en vez de ostentación de miseria, trataba de ocultar su pobreza y, como dice Cervantes, estando aún en ayunas en altas horas del día, salía a la calle limpiándose los dientes para hacer creer que ya había almorzado (Palacios, 1960: 46).

Esta postura autoral marca, junto con las alusiones a lo urbano, la principal diferencia con «María». Mientras Palacios se empeña en trasladar lo más fielmente posible las formas de vida europea a América, incluyendo y legitimando como positiva la presencia de personajes como Juan Zamora, Isaacs opta por otros modos de construir región. Con esto no se busca negar que él también descansó su novela sobre el conjunto de tradiciones heredadas de la Colonia; aludiendo en particular a las religiosas y a la jerarquización social de tipo patriarcal. No obstante, su novela tiene un carácter mucho más práctico en lo político: la reinterpretación de la historia y la presencia del negro en Colombia. Mientras Palacios ubica a Zamora dentro del epicentro del poder, es decir, la casa del alférez, y a través de esto refuerza positivamente la presencia extranjera en el país, Isaacs replantea los modos tradicionales en que se relacionaban los negros esclavos y los señores de la principalía. ${ }^{1}$ Por consiguiente, lo que se produce a partir del discurso literario es una valoración más auténtica y secular de la realidad sociodemográfica colombiana, de su mixtura, limi-

1. Véase, por ejemplo, la escena de la caza del tigre en la cual el joven Efraín obedece al colono José. 
taciones y reivindicaciones. El negro, que desde ningún punto de vista es redimido de la esclavitud, es observado como un sujeto con evidentes deberes, pero también con derechos otorgados por la ley que representaban las élites.

Desde esta perspectiva, «María» es también una novela clasista en la que se defienden los valores burgueses y los modos de producción económica propios de la élite terrateniente. Sin embargo, el elemento novedoso para la época radica en la sugerente construcción de un proyecto regional en el que los subalternos fueran ganando no solo románticas consideraciones paternalistas, sino espacios concretos dentro del ámbito institucional en Colombia. Si en «El Alférez Real» es el español quien ingresa al centro del poder, es decir, a la hacienda del alférez don Manuel, en «María» es el negro quien lo hace a la hacienda del padre de Efraín.

Cuando la novela de Isaacs introduce, tangencialmente desde luego, al negro al interior de la casa patriarcal -piénsese en Nay, por ejemplo-, se propone una variación en las formas de relación con el poder: el espacio privado se abre al subalterno para «nivelarlo», para dotarlo de acceso al centro, espacio siempre excluyente, vedado e inexpugnable. En virtud de ello, y dado el trato ciertamente afable hacia las negritudes, podría llegar a pensarse que en «El Alférez Real» también se produce una integración demográfica reivindicativa que se suma al carácter multiétnico del país; no obstante, lo hecho por Isaacs en «María» es de un tenor mucho más significativo.

Dadas las diferencias entre el lugar de por sí hegemónico de España en América y la voz subalterna de África como continente colonizado, no colonizador, es preciso decir que la presencia de la negritud que se propone en «María» se amalgama con la emergencia de las masas que en Colombia estaban completamente por fuera de los círculos de poder. Mientras en «El Alférez Real» Zamora se integra gozosamente al centro de la toma de decisiones, en la novela de Isaacs hay una reivindicación incipiente de los subalternos negros que ocupan un importantísimo porcentaje en la constitución demográfica de la nación y más del Valle del Cauca. Mientras en la novela de Palacios se aboga por mantener una tradición social y racial de cuño ibérico, en la de Isaacs se esboza la ampliación o modificación gradual de la misma. Es por esta razón que el dominado accede muy lentamente a ganarse un espacio dentro del contexto hegemónico.

Se insiste en lo lento del proceso de consecución de espacio, reconocimiento y consideraciones puesto que, en ambas novelas por igual, son evidentes las marcas de diferenciación de clases. De tal suerte, un aspecto a destacar en torno a los distanciamientos de la sociedad burguesa y la popular se explica a través de la educación. Se alude en particular a la de los hijos del alférez real y a la de los hijos de los otros ricos del Valle. Dice la narración de Palacios (1886): 
Si no había médicos sí había abogados, graduados en Santafé o en Quito, y todos ellos de las principales familias. No había colegios: los hijos de los pobres solían aprender algo con los frailes. A los colegios de Santafé y de Quito solo iban los hijos de los nobles, para lo cual se hacían informaciones de limpieza de sangre (70).

Esto puede explicarse con claridad a partir de lo planteado por el crítico Jonathan Brown (1980) en su artículo «La tradición cortés en la cultura colombiana del siglo XIX»:

Los nobles y los hombres de letras se educaban en un sistema pedagógico de acceso limitado, que hacía hincapié en la educación clásica y en el refuerzo de los valores conservadores de las clases altas colombianas. Aunque en 1913 el número de estudiantes de las escuelas públicas superaba al de las privadas en una relación 16 a 1, la educación pública en el siglo XIX fue estadísticamente de menor peso. Entre 1873 y 1883, el gobierno cerró muchas escuelas públicas y el número real de estudiantes disminuyó. En todo caso, las escuelas privadas proporcionaban la educación para la élite, y en muchas ocasiones estaban ubicadas en los hogares mismos de los literatos, como José Joaquín Ortiz o Santiago Pérez. Por 204 pesos al año, pagaderos trimestralmente por adelantado, los hijos de la aristocracia estudiaban idiomas, estética, redacción, gramática, moral religiosa y el dogma católico. La lista de libros incluía siempre textos de historia sagrada e instrucción religiosa. Además, por seis pesos mensuales, los tutores iban a las casas de la élite tres veces a la semana para las clases de idiomas extranjeros. Las niñas iban a los internados -las visitas eran los domingos en la tarde- donde recibían lecciones de música, manualidades y urbanidad, además de la obligatoria educación religiosa. En una sociedad percibida como depravada y corrupta, la formación católica buscaba disciplinar a un individuo que de otra manera estaría inclinado al mal (5).

La cita en mención sintetiza, de manera precisa, el rol diferenciador de la educación tanto en «El Alférez Real» como en «María»: los hijos de don Manuel, al igual que Efraín, disfrutaron de una vasta formación académica dentro y fuera del país, como estipulaban las costumbres de la élite del siglo XIX en Hispanoamérica. De los herederos del alférez se comenta lo siguiente: «los hijos varones de don Manuel estaban ausentes: don Manuel José, don Fernando y don Joaquín, en Popayán, en el Real Seminario de San Francisco de Asís; y don Manuel Joaquín en Cali, estudiando con los Padres de la Merced» (Palacios, 1960:16). A su vez, Efraín salió de la hacienda de su padre a cursar estudios de secundaria en Bogotá para ir, posteriormente, a Londres a estudiar medicina. No obstante, en la novela de Palacios es mucho más acentuado el distanciamiento de clases según las condiciones de riqueza, pobreza o linaje de sangre. Da fe de ello este fragmento del capítulo VIII, «La pascua»: 
El intruso que quiso cargar el palio se dio por ofendido por la vergüenza que se le había hecho pasar de una manera tan solemne, y después de la pascua se quejó ante las autoridades de la violencia de que había sido víctima. Se siguió juicio ante él y el Cabildo; ese juicio fue a la audiencia de Quito y por último a España; el Alférez real era el principal sostenedor del pleito. Al cabo de tiempo vino la sentencia definitiva en que se declaraba que ese tal no tenía derecho a cargar vara de palio. Pero había habido otra insolencia del mismo género. El día de pascua un señor Juan Núñez se había atrevido a salir a la calle con capa colorada. El Alférez Real, que tal lo vio, ordenó a su paje Roña que le arrancara de los hombros la capa a ese sujeto: este se defendió vigorosamente contra el criado; el Alférez Real se presentó ante la autoridad competente quejándose contra Núñez, por usurpación de honores. Pero Núñez era hombre de recursos y aceptó el pleito y lo sostuvo en todas las instancias y con todas sus fuerzas, sin omitir gastos. Este pleito, como aquel otro, fue a la audiencia de Quito y, por último, a España. Después de dos o tres años vino la sentencia en que se declaraba que Núñez tenía perfecto derecho a usar capa colorada y espadín, porque había probado plenamente la limpieza de su sangre (Palacios, 1960: 81).

A modo de conclusión, es preciso decir que ambas novelas dan cuenta de las formas de vida de las élites. Sin embargo, en ese proceso aparentemente homogéneo, «El Alférez Real» resulta ser más explícita en el refuerzo de los valores burgueses que dificultaron la construcción de un tejido social más amplio y mejor integrado. La defensa del legado español, la presencia de hidalgos castellanos y la fidelidad a los designios del rey, hacen de esta novela un texto que se distancia totalmente de cualquier vinculación con la secularización como proceso socio histórico en Colombia. Lejos de plantear alguna separación de poderes o relecturas de las dinámicas de poder, se produce un refuerzo de los esquemas de vida conservadora.

Podría pensarse que el señalamiento es extremo dado que «María» también gira en torno a ejes temáticos comunes; sin embargo, no es así porque, en el tratamiento a los esclavos, Isaacs realiza una incorporación simbólica y metafórica al cuerpo de la patria, que es la hacienda de su padre, como ya se ha señalado, lo que no sucede en la narración de Palacios. Decimos esto pues Daniel, quien en apariencia era el «otro», el que resultaba diferente y pobre, es finalmente integrado al centro del poder una vez es comprobado su parentesco con el alférez don Manuel. Así, pues, lo que plantea la novela es la consolidación y el arraigo de una sola clase social: la burguesía. Daniel deja de ser ese «otro» despreciable y de representar «a los otros» para ser un integrante más de la hegemonía. Su condición de joven educado, blanco, rico y esposo de una mujer también poderosa lo convierte en un continuador de la tradición clasista en el Valle del Cauca. 


\section{La moral como elemento diferenciador entre las novelas, como condición de superioridad ante los otros}

Parte del asentamiento de la burguesía que se narra en ambas novelas, y que transcurre en el Valle del Cauca, pasa por un hecho concreto: la tenencia de una elevada moral que no se puede comprar, pero que se gana a fuerza de prodigalidad, bondad, linaje e historia. Se hace referencia a esto pues muchas de las revisiones críticas de estas obras han planteado reflexiones que explican, tanto el papel de la rectitud ética, como de la probidad espiritual en relación con la construcción de región, mas se quedan cortas a la hora de evidenciar un elemento diferenciador entre ambos patriarcas. A esto se llegará más adelante mediante la revisión minuciosa de un aspecto puntual de las tramas. En ese sentido, interesa abrir, si así se quiere, una nueva línea de análisis de cara a futuras lecturas filosóficas u ontológicas de los textos, modalidades de indagación que poco se han abordado.

Más allá de los asuntos religiosos cotidianos (asistencia a misa, cumplimiento de rezos y devocionales, construcción de capillas en haciendas y plazas públicas, etc.), es importante llamar la atención, en primer lugar, sobre las calidades morales que instalan, tanto al padre de Efraín como al alférez don Manuel, en la cima de la pirámide social del Valle del Cauca novelado. Este ejercicio resulta viable pues en cada narración se tipifica el modelo de hombre ideal, es decir, el modelo de padre fundador de las diferentes regiones del país. No debe olvidarse que, como bien señala Idelber Avelar (2015) en su texto «Transculturación en suspenso: los orígenes de los cánones narrativos colombianos», Colombia fue llamada, desde 1863 hasta 1886, Estados Unidos de Colombia, apelativo que da por sentada la tentativa de implementar un modelo de conformación territorial no centralista, sino federalista; proyecto que fracasó con el advenimiento del gobierno de Rafael Núñez.

Así las cosas, y si bien es cierto que Isaacs fue primero conservador y después liberal radical (esto último hacia 1870, aproximadamente), sus personajes no contravienen jamás las buenas costumbres tanto sociales como católicas y conservadoras. El padre de Efraín se muestra siempre laborioso y cumplidor de los deberes que en suerte le tocan, así se trate de los que tiñen de sentimentalismo la novela: «A la mañana siguiente mi padre desató de mi cabeza, humedecida por tantas lágrimas, los brazos de mi madre» (Isaacs, 1967:14). En esta clave, Isaacs dota al patriarca con todas las virtudes que definían, más allá de lo político, a los caballeros de la época. En virtud de esto puede señalarse que el autor mantiene, con la figura del padre, el espíritu conservador y tradicional que el joven Efraín, tímidamente, intenta vencer cuando dice, por ejemplo, que dada la difícil situación económica familiar no estima conveniente su viaje a Londres para cursar estudios de medicina. 
Desde otra perspectiva, y si bien las insinuaciones eróticas que ha estudiado María Ximena Hoyos Mazuera (2010) tocan la puerta de la familia de Efraín, jamás involucran al padre de este. En tanto referente moral, el patriarca jamás se ve envuelto ni en aventuras por fuera del matrimonio, ni en encubrimientos de amores prohibidos. De hecho, al interior de la familia del joven protagonista hay un tan alto valor asignado a la pureza que se traduce, incluso, en el recatado vestir de María. Según Hoyos Mazuera (2010), y de acuerdo con la tradición religiosa, «un cuerpo vestido es un cuerpo de virtud para cualquier habitante neogranadino de los siglos XVI y XVII. Los negros, mulatos y mestizos eran asociados con el mal por no tapar sus genitales, mientras que los blancos vestidos que taparan su sexualidad eran asociados con lo bueno y con Cristo» (38).

En adición a esto, hay que hacer énfasis en que el padre de Efraín no actúa como celestino. Lejos de validar realmente el endogámico amor entre su hijo y su entenada, al que aparentemente no le ve ningún problema contractual más allá de la enfermedad de María, se ocupa de sofocarlo como estrategia para preservar la delicada salud de sus finanzas. Efraín no puede distraerse, a su edad y en su condición de heredero, de los asuntos prácticos que sellarán la suerte de la familia una vez muera su progenitor. En ese sentido, el viejo patriarca se encuentra lejos de cualquier pasión que enturbie su superioridad moral. Como si fuera poco, es noble casi hasta la caricaturización y leal en las empresas, como la cristianización de María, que empeñan la bienaventuranza de la familia. En relación con los trabajadores de las haciendas goza de total superioridad, no solo por ser el dueño de estas, sino por perdonar diversas pilatunas, a veces, y en otras oportunidades verdaderas trapacerías y perjurios. En síntesis, puede decirse que no se evidencia en la novela una fractura grave que dé cuenta de deterioro moral alguno por parte del padre de Efraín. Quizá el único momento de abatimiento interior acontece cuando muere la joven María y surge la congoja por «fallarle» a Efraín. A raíz de ese mismo suceso, y como se mencionó en páginas anteriores, también surge un estremecedor abatimiento: el imaginario reclamo de Salomón por su fallecida hija.

A su vez, «El Alférez Real» perfila, también, cómo don Manuel de Cayzedo y Tenorio es superior a todos los moradores de Cali en los albores del siglo XVIII. Su elevada conciencia de quién es, por un lado, y su rectitud en los asuntos prácticos de la vida cotidiana, por otro, le granjean un lugar privilegiado en el concierto de la comarca vallecaucana. Al igual que el padre de Efraín, el alférez también es celoso. No tanto por evitar el surgimiento de amores endogámicos, lo cual debería generar en sí una turbación, sino por la preservación de la riqueza, honor y linaje de su familia. Ahora bien, esto no habilita la presunción de que el alférez sea un ser sin escrúpulos, pues de hecho tiene bastantes; por el contrario, es la emergencia de los celos lo 
que eleva y define su concepto del bien. En el caso del amor entre Inés y Daniel, el alférez es leal, al igual que el padre de Efraín, a su fallecido primo. El juramento de cuidar y proteger a la joven se erige como una de las empresas que más compromete sus energías vitales. Así, entonces, la desaprobación del romance entre los jóvenes se lee como un acto que preserva la moralidad e integridad de una clase social que debe estar «limpia» para dirigir los destinos regionales.

De acuerdo con Seymour Menton (2007), y partiendo de las características intrínsecas de la novela decimonónica en Hispanoamérica, es dable captar en esta «el antagonismo entre los ricos y los pobres, los calzados y los descalzos» (44). El distanciamiento, que se manifiesta principalmente por asuntos de poder económico, también incorpora claramente una moral propia de los grupos hegemónicos que pretenden distanciarse del vulgo y sus maneras hostiles y soeces; de su precaria forma de ver e interpretar el mundo en tanto epicentro de lo poco y lo precario; de su ascenso social que no podía sino enturbiar el desarrollo de una élite inspirada por Francia e Inglaterra en lo político y lo artístico. De acuerdo con el profesor Juan Carlos Jurado (2010):

Durante el siglo XIX se presentaron nueve guerras civiles en la Nueva Granada (1830, 1839-1842, 1851, 1854, 1859-1862, 1876, 1885, 1895 y 1899-1902) como parte de los procesos de formación de la nación, que significaron un drama de dolor y sangre para la masa del pueblo llano, pero también una oportunidad de ascenso social, ya fuera por acciones heroicas ligadas a la carrera militar o por medios menos santos como el robo y el saqueo (51).

Si bien los métodos usados para el ascenso explican en sí los duros procesos de separación social y, subsecuentemente, las diferentes perspectivas éticas y morales de los grupos que conformaban la incipiente nación en el siglo XIX, cabe aludir ahora al elemento diferenciador entre ambas novelas. Más allá de las muchas similitudes en cuanto al perfil económico y moral de los protagonistas, es pertinente evaluar un hecho poco advertido por la crítica desde un ejercicio comparado entre «María» $\mathrm{y}$ «El Alférez Real»: el encubrimiento, por parte de don Manuel, del romance que sostuvo su primo, Henrique Cayzedo, con Dolores Otero, y del cual nació Daniel.

De acuerdo con la estructura de la novela, el joven es presentado como un muchacho pobre que, en primera instancia, es criado por Mariana Soldevilla, una mujer humilde de la comarca, para después ser incorporado a la hacienda de don Manuel por intermediación del padre Escobar, de lejos, y en realidad, el único personaje con una moral intachable a lo largo de toda la narración. En el trance del ingreso a la hacienda parece distraerse el lector que rápidamente cae en la hipnosis de la trama romántica y la anécdota idílica. No obstante, hay que revisar las circunstancias en las cuales 
se da el romance entre el primo del alférez y Dolores, situación que a todas luces vulnera tanto la diferenciación cultural, como la resistencia del mismo alférez ante la aproximación de clases, con lo cual se fragmenta su sólido discurso monológico.

Es claro el texto al precisar que el clandestino romance, que llega hasta el casamiento, acontece en los años mozos tanto del alférez como de su primo, con lo cual intenta instalarse una lectura inocente, casi pueril, que se escuda en la juventud para dar trámite a una acción indebida que no se repetirá en la adultez con la díada que conforman Inés y Daniel. Dada la cercanía y el afecto entre don Manuel y Henrique, el primero acepta ser padrino de bodas del segundo. A esto se suma también la complicidad del padre Escobar, a quien no se le pueden endilgar resquebrajos morales, puesto que actúa conforme a las leyes eclesiásticas y además en nombre del amor como ideal romántico por excelencia.

De modo contrario, don Manuel evidencia una doble postura que fragmenta la solidez de su discurso hegemónico. En primer lugar, y sin perder de vista su adscripción a la élite portadora de valores y prejuicios, legitima mixturas de clase promovidas por el deseo y el deslumbramiento, ambos, indiscutiblemente, precipitaciones del carácter. ¿Por qué no puso reparos a su primo cuando le contó sus planes? ¿Por qué en nombre del amor-deseo renunció a su altura moral y a su no contravención de las normas instauradas por la tradición? ¿Por qué sí tuvo amonestaciones serias y severas cuando se enteró de los planes de Inés y Daniel? ¿Por qué, en nombre del mismo amor-deseo que una vez tuvieron su primo y Dolores, no renunció a su altura moral y se permitió contravenir las normas para que se consumara la unión de los jóvenes?

Estas preguntas dan paso a la segunda acción que enturbia la honestidad del alférez, es decir, al silencio ante la concurrencia de un hecho infame: la boda de su primo y Dolores. A la participación como padrino de la misma se le suma un hecho mucho más grave: mantener el referido silencio que el joven le implora. Si por una parte lo desdibuja ser partícipe del casamiento, más lo hace, por otra, ser cómplice del mismo. En la medida en que el silencio se guarda como secreto se fractura su personalidad incorruptible. El aceptar tomar parte en algo viciado permite cuestionar lo parejo y armónico de su comportamiento a lo largo de la narración.

Ahora bien, todo terminaría siendo mucho más sórdido de no haberse esclarecido el nacimiento de Daniel. El niño, producto de aquel amor irregular, fue dado por precaución de la propia Dolores Otero a Mariana Soldevilla para que esta, a su vez, lo entregase a su padre cuando aconteciera su retorno a la región. De no aclararse esto, el ocultamiento sería leído como un intento más por evitar el escándalo que supondría el romance entre un hombre de la principalía y una mujer plebeya como Dolores. Ahora, cierto es que el alférez ignoraba el nacimiento del niño: «-¿Un niño?-repitió don Manuel, alzándose violentamente del asiento-¿Y en dónde está?» 
(Palacios, 1960: 155). No obstante, su silencio ante la boda legitima todo cuanto esconda, enmascare o disimule la relación de su primo con la joven, denominada a la sazón como «la Flor del Vallano». Un asunto muy problemático hubiera surgido si, una vez fallecido el ardoroso amante, y enterándose en aquellos años del nacimiento de Daniel, el alférez hubiera querido acogerlo en su familia. ¿Qué hubiera pasado con Dolores de haber sobrevivido, qué hubiera pasado si Mariana Soldevilla hubiese revelado quién era la madre del menor? Nótese como el capítulo XXV, «Confidencias», regresa en el tiempo al alférez para enfrentarlo con el pasado.

El padre se quedó pensativo. De repente, fijando los ojos en don Manuel, le preguntó: -¿Se acuerda de Dolores Otero? Don Manuel se puso de pie. -¿Dolores Otero? ¿Cómo sabe ese nombre? -La agitación de don Manuel era notable. -Hace muchos años usted guarda ese secreto, y piensa que nadie más en el mundo lo sabe. -¿Cómo llegó usted a saberlo? -Ahora se lo diré... Le propongo un trato: usted sabe una parte de esa historia. Cuéntemela, y yo le contaré lo que sé, que es mucho más. -No tengo inconveniente, compadre, antes me alegro de hallar al fin una persona de toda mi confianza, con quién poder hablar de esos tristes recuerdos. -Hace de eso veinticinco años, pero todo lo recuerdo con tanta viveza como si hubiera sucedido ayer. ¿Conoció a don Henrique de Cayzedo? -Sí, compadre, lo conocí, pues apenas hará diez años que murió. Don Henrique de Cayzedo era mi primo. Hacía estudios de Derecho en la ciudad de Quito, y cuando ya estaba próximo a coronar su carrera, vino aquí de paseo en unas vacaciones. ¿Qué talento tan claro y qué corazón tan magnánimo! Lo tenía todo. Jamás alguien ha ejercido sobre mi espíritu una influencia más grande. Yo lo amaba como si fuera mi hijo. Había entonces en Cali, en el barrio del Gran Padre San Agustín, una muchacha hermosa pero plebeya, llamada Dolores Otero, los pocos que la conocían le habían dado el sobrenombre de la Flor del Vallano. «Mi primo conoció a Dolores Otero una tarde -continuó don Manuel- y la pasión que sintió por ella fue la más violenta que haya dominado jamás el corazón de un hombre. Ella no tenía madre, y su padre, que andaba en los sesenta y cinco años, estaba enfermo de reumatismo. Una criada vieja les servía, y no había otra persona en la casa. Era una familia pobre y vivía únicamente del trabajo de Dolores, que era la mejor costurera del barrio. Comenzó, pues, a perseguir a la pobre muchacha con su amor desesperado y loco, pero en esa mujer de escasos dieciocho años encontró una roca. Argumentos, ruegos, obsequios, promesas... todo fue inútil, y esa resistencia avivaba el fuego que lo devoraba. «Una noche, cuando él pensaba haberla convencido con sus argumentos, ella le dijo que no insistiera más, que ella sabía cuáles eran sus virtudes y sus limitaciones y que las reglas de la sociedad jamás les permitirían una unión. Era una mujer orgullosa de su origen y su dignidad. Él se quejó de su insensibilidad y de lo poco que valoraba su amor. Ella le contestó que no era insensible sino realista. Conozco y acepto la posición que Dios me dio, dijo, y le confesó que había un joven carpintero que le había propuesto matrimonio, y que tal vez 
lo aceptaría porque era del gusto de su padre. La lucha continuó por varios días hasta que consiguió convencerla, convinieron un matrimonio en secreto y él le prometió que al cumplir los veinticinco publicaría su enlace y la presentaría al mundo como su esposa legítima. «Un amigo quiteño que regresaba de Santafé a Quito pasó a visitar a Henrique, que resolvió aprovechar para irse acompañado, porque ya habían terminado las vacaciones. Cuando Dolores supo que su amante se iría dentro de quince días, casi se muere. «Una noche, estando yo en mi cuarto, se presentó Henrique acompañado del caballero quiteño y me dijo: -He resuelto casarme con Dolores. -¿Casarte con Dolores? -Exclamé asombrado- ¿Estás loco? ¿Piensas siquiera en lo que dices? -Lo tengo bien pensado y es cosa resuelta. El favor que te pido es que me sirvas de padrino. Al oír esto, salté de mi asiento como un resorte. -Ahora sí no me queda duda de que has perdido el juicio -le dije-. ¿Autorizar con mi presencia semejante despropósito? ¡Jamás! (Palacios, 1960: 150-152).

Tras el fragmento varias cosas quedan en evidencia: en primer lugar, que lo del primo de don Manuel pasó, principalmente, por los arrebatos de la pasión y el deseo (varias son las marcas textuales que así lo explican y ponen en tela de juicio su seguimiento de las tradiciones); en segundo lugar, que la resistencia/negación del alférez para vincularse a la realización de la boda, y que casi obliga a su primo a buscar otro testigo, puede leerse como un gesto de fraternidad que, no obstante, contraviene una postura moral); y, por último, que la joven Dolores se sabía notoriamente inferior a su pretendiente. En ese orden de ideas, y para concluir, solo resta decir que las manifestaciones de rectitud estuvieron, en ambas novelas, pero sobre todo en «El Alférez Real», supeditadas a intereses, conveniencias y silencios cuyo fin era preservar la élite como clase social dominante. Así, pues, bien valdría preguntarse ¿Qué tan genuina es una conciencia, individual o colectiva, que esté mediada o en función de lo económico o de las sanciones de clase?

\section{Referencias}

Álvarez Gardeázabal, G. (200o). La novela colombiana. Entre la verdad y la mentira. Bogotá: Plaza y Janés.

Avelar, I. (2015). Transculturación en suspenso: los orígenes de los cánones narrativos colombianos. Bogotá: Instituto Caro y Cuervo.

Bermúdez, I. (2008). El ángel del hogar: una aplicación de la semántica liberal a las mujeres en el siglo XIX andino. Quito: Universidad Andina Simón Bolívar. 
Brown, J. (1980). La tradición cortés en la cultura colombiana del siglo XIX. The Americas, XXX$V I(4), 445-464$.

Eco, U. (1992). Los límites de la interpretación. Barcelona: Lumen.

Florián-Buitrago, M. (2008). La María de Jorge Isaacs y su aporte en la construcción de la identidad de los sujetos. Bogotá: Universidad Colegio Mayor de Cundinamarca.

Henao, D. (2005). Memorias del primer simposio internacional Jorge Isaacs: el creador en todas sus facetas. Cali: Universidad del Valle.

Hoyos-Mazuera, M. (2010). Erotismo velado y decoro en María, de Jorge Isaacs. Cali: Universidad del Valle.

Isaacs, J. (1967). María. Cali: Norma.

Jitrik, N. (2005). El secreto encanto de Jorge Isaacs. En Darío Henao Restrepo (comp.), Memorias del primer simposio internacional Jorge Isaacs: el creador en todas sus facetas (pp. 63-70). Cali: Universidad del Valle.

Jurado, J. (2010). Pobreza y nación en Colombia, siglo XIX. Revista de Historia Iberoamericana, $3(2), 47-71$.

Kushner, E. (2009). Articulación histórica de la literatura. En Teoría literaria (pp.125-144). México: Siglo XXI Editores.

Martín-Jiménez, A. (2014). Intentio auctoris e intentio operis: intención manifiesta e intención encubierta en Cervantes y Avellaneda. Valladolid: Universidad de Valladolid.

Menton, S. (2007). La novela colombiana:planetas y satélites. Bogotá: Fondo de Cultura Económica.

Pineda-Botero, A. (1999). La fábula y el desastre: estudios críticos sobre la novela en Colombia. 16501931. Medellín: Eafit.

Palacios, E. (1960). El Alférez Real. Bogotá: Universales.

Vásquez-Benítez, E. (2001). Historia de Cali en el siglo XX. Sociedad, economía, cultura y espacio. Cali: Universidad del Valle. 